\title{
When the Leader is Born as A Competitor (WLBC)
}

\author{
Agus Maulana ${ }^{1 *}$, Raju Maulana ${ }^{2}$ \\ ${ }^{1}$ Economic and Bussines Faculty, Universitas Riau Pekanbaru \\ ${ }^{2}$ Economic and Bussines Faculty, Universitas Islam Indragiri \\ Email: agusmualanaunisi@gmail.com ${ }^{1 *}$, rajumaulana88@gmail.com ${ }^{2}$
}

\begin{abstract}
The presence of humans on earth is a gift of leadership and humans are born with their destiny as leaders for themselves, their families, and the surrounding community. The challenges that are faced every day are important factors in shaping the character of one's self and soul so that it has implications for a leader when taking part in society. Jokowi as a figure of a leader who was forced by circumstances, his family, and society formed himself into a leader with a different character, and it is said that an expert is a Servant Leader. Methodology qualitative and narrative descriptive analysis methods on literature review. Comparisons of expert opinions and theories as well as relating several important events in the lives of characters through audio and video as well as real-life stories. Jokowi's leadership has become an inspiration for many people so that the author is interested in seeing and observing more deeply from the historical side of Jokowi, from the selectivity of a biography and the history of success as a company leader, major, governor and president, this is also what makes the writer's way of thinking finding a new view of leadership theory which is referred to in the term WLBC, along with the many theories of styles and characteristics and types of leadership by previous experts, writers and researchers. There are three finding factors that strongly influence the formation of Jokowi's character which are applied in ten indicators, three factors including family, community, and personal responsibility.
\end{abstract}

Keywords: Leader, Competition, Servant, Jokowi.

\section{Introduction}

when the prospective leader wants to be a new leader, Humans are born into the world as the fruit of love or when the leaders have sat on their throne or even from two human partners who are aware of the when someone has started to take part in society, and happiness they hope for in the future. Each of us is a the phrase begins to appear and began to be talked leader for ourselves to be able to stand tall on the about by the public without realizing that the leader surface of this earth to be able to face situation after was a competitor and had won the trophy. And this situation every day, challenge after challenge that story can be an inspiration for the community and if the makes him become a competitor. We are trained and character is relevant or by the way of life or according guided out of the family environment in the household to or there is something in common with their life to the school environment and the community. It is not history then this will strengthen the community's surprising that without realizing it, educational sympathy and respect for the leader. This is where institutions contribute a lot to form the leader into a sympathy, admiration, and excitement begin to emerge competitor with the existence of a class champion to a leader, based on support from information obtained assessment system and even to the grouping of favorite whether word of mouth, or reading a media, or directly and ordinary schools.

meeting and face to face with the figure at an event, or

Since childhood, our parents, father or mother even with purposely came to meet.

have imagined in their minds that in the future their Since childhood, our parents, father or mother children will achieve their dreams as the hope of the have imagined in their minds that in the future their parents so that the children become useful people for children will achieve their dreams as the hope of the society, the nation, and the country, when words are parents so that the children become useful people for spontaneously expressed. or the parent's prayer to the society, the nation, and the country, when words are child so that he becomes a leader. This was revealed spontaneously expressed. or the parent's prayer to the and written by many biographers and even made a film, child so that he becomes a leader. This was revealed 
and written by many biographers and even made a film, demonstrations everywhere in the state can be used as a when the prospective leader wants to be a new leader, tool to overthrow the regime of power and are or when the leaders have sat on their throne or even considered legitimate laws to replace positions, and when someone has started to take part in society, and supported by spreading hatred on social media, leaders the phrase begins to appear and began to be talked are not to be praised or to respect his kindness and if about by the public without realizing that the leader there is an error that is felt, convey it in secret which was a competitor and had won the trophy. And this will inspire his soul to make changes in the future, and story can be an inspiration for the community and if the will listen to and pay attention to the voice of the character is relevant or by the way of life or according people, this inspires the author to choose the figure of to or there is something in common with their life Jokowi in this paper. The author acknowledges that history then this will strengthen the community's several times he has been the Chairperson and sympathy and respect for the leader. This is where Secretary of the Presidential Election Success Team at sympathy, admiration, and excitement begin to emerge the District Level, especially in Indragiri Hilir to a leader, based on support from information obtained Regency.

whether word of mouth, or reading a media, or directly meeting and face to face with the figure at an event, or re even with purposely came to meet.

Muhammad Nurdin Fathurrohman's coverage reveals (2013) Joko Widodo was born in Surakarta, Central Java on June 21, 1961; the age of the couple Noto Mihardjo and Sujiatmi. Joko Widodo Notomiharjo is the eldest son and the only son of four

\section{Literatur Review} In 1978, Michael H. Hart who is a Jewish descendant children. He has three younger sisters named
wrote a book entitled " The $100 "$. The book contains IitSriyantini, Ida Yati and Titik Relawati. Before 100 figures who have had the strongest influence in changing his name, Joko Widodo had the first name human history. This much debate book has widely Mulyono. His father came from Karanganyar, while his imitated concept. It's important to note that Hart didn't grandparents came from a Desa in Boyolali. His include the greatest man. The criterion is an influential education began with entering SD Negeri 111 person. This book was reprinted in 1992 with several Tirtoyoso, which is known as a school for the lower noticeable revisions to the list of 100 and their middle class.

extraordinary rank 100 People according to Michael H. With life's difficulties, he was forced to trade, Hart by Ranking and Influence The Prophet ride an umbrella, and become a coolie to find his own Muhammad: The propagator of Islam, the ruler of school needs and pocket money. When other children Arabia, had an extraordinary political and religious ride their bicycles to school, he chooses to keep career, however remain balanced and harmonious, walking. Inheriting carpentry from his father, he started resulting in the Prophet Muhammad to have many working as a sawmill at the age of 12. Little Jokowi has followers, and also become a role model for the whole experienced the eviction of his house three times. The world community to this day. Hart views Muhammad evictions he experienced three times in his childhood as the most influential figure in human history. influenced his thinking and future leadership after

According to Hart, Muhammad was the only becoming Mayor of Surakarta when he had to put person who succeeded in achieving extraordinary people in order. After graduating from elementary success in both spiritual and social terms. Hart noted school, he then continued his education at SMP Negeri that Muhammad was able to manage a nation that was 1 Surakarta. When he graduated from junior high initially selfish, barbaric, backward, and divided by school, he wanted to enter Surakarta 1 Public High tribal sentiments into a nation that was advanced in the School but failed so that in the end he entered the economic, cultural, and military fields and even Surakarta 6 Public High School.

defeated the Roman troops which at that time was the Jokowi married Iriana in Solo, December 24, foremost military force in the world. That the author 1986, and has 3 children, namely Gibran takes a message from the figure of the Prophet RakabumingRaka (1988), KahiyangAyu (1991), and Muhammad who advised through his Holy Book that KaesangPangarep (1995). With his academic abilities, we must obey the Creator, then we must obey the he was accepted at the Department of Forestry, Faculty Prophet based on our religion and belief in the basic of Forestry, Gajah Mada University. He used this conformity of the country, and the third must obey the opportunity to study wood structure, its utilization, and leaders in our respective regions. is, even teaching technology. He completed his undergraduate thesis ethics in admonishing a leader who is in power is not entitled "The Study of Plywood Consumption Patterns by carrying out demonstrations that can cause great in End-Use at the Surakarta Municipality".

chaos and loss, namely by taking advice, and After graduating from UGM Forestry Degree conveying criticism to the leader can only be done with in 1985, he worked at state-owned PT Kertas Kraft four eyes because the leader is considered a destiny that Aceh and was placed in the Mercusii Pine Forest area has been outlined. and must be recognized for his in the Gayo Highlands, Central Aceh. But he felt leadership and not dropping his face in public, uncomfortable and came home to follow his wife who 
was seven months pregnant. He was determined to do business in the timber sector and worked for Pakdenya's business, Miyano, under the banner of CV 3 RodaJati. In 1988, he ventured to open his own business under the name CV Rakabu, which was taken from the name of his first child. His business was 4) successful and he also fluctuated because he was deceived by an order that was not paid for. However, in 1990 he rose again with a capital loan of IDR 30 million from his mother.

This effort led him to meet Bernard Chene, a 5) businessman from France, who eventually gave him the popular nickname "Jokowi". With his honesty and hard work, he won the trust and was able to tour Europe which opened his eyes. A good city regulation in Europe inspired him to apply in Solo and inspired him 6) to enter the world of politics. He wants to apply human leadership and create a city that is friendly to its inhabitants.

\section{Method}

Qualitative and narrative descriptive analysis methods on literature review. Articles and comparisons of expert opinions and theories as well as relating several important events in the lives of characters through audio and video as well as real-life stories. The variables in the narrative make a frame of mind $\mathrm{X}_{1}+\mathrm{X}_{2}+\mathrm{X}_{3}=\mathrm{Y}$ where $\mathrm{Y}=$ WLBC Leadership Style, $\mathrm{X}_{1}=8$ ) Family Factor (FF), $\mathrm{X}_{2}=$ People Factor (PF), $\mathrm{X}_{3}=$ Personal Responsibility (PR) is thought to influence the Dependent Variable.

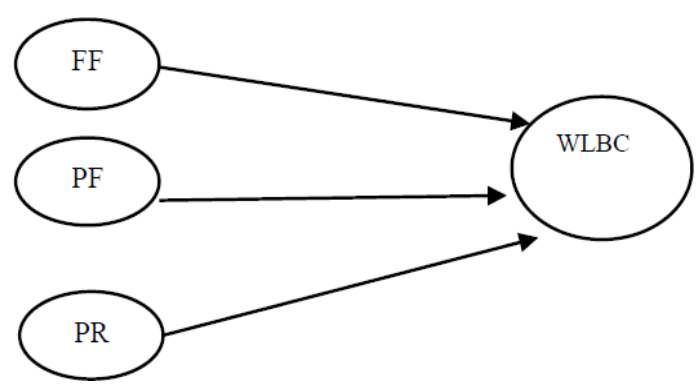

Figure 1. Conceptual Framework

\section{Result and}

\section{Discussion Result}

From the little biography of the character description Jokowi, the authors wanted to find a new perspective on the concept of "Whether leaders are born competitors, theory (WLBC)", whether leaders are born as a competitor" that they seem to merging as right several matters, among others are:

1) Jokowi was born not from a family with a previous leader background or a family of officials, namely from a family of simple people (Low Profile).

2) Jokowi has planted a determination in him, a vision since the three times his house was demolished and it was stuck before he was 12 years old (Leader is Visionary).

3) Jokowi has been trained to live honestly and work hard to help families in difficult livelihood (Honestiness and Hardworkness).

Jokowi since the age of 12 years has inherited the trade of carpentry and has started to grow soul entrepreneurship evident after graduated he was not at home working in the company and returned to the air entrepreneurs. (Entrepreneur Leaders).

Jokowi is steadfast in facing challenges and is confident that his business will succeed despite the many obstacles he has faced and finally has a balanced business partner. (Balance of Challenge and Believe).

6) Jokowi does not neglect the opportunity and mandate of his work, according to his determination and vision as a child and the realization that he will become a regional leader later. (Opportunity and Trusts).

7) Jokowi obedient leadership and urgent circumstances when asked to become head of the higher powers and responsibilities, but thanks to the trust and sympathy, he took the opportunity and mandate run with confidence, determination, and experience of the past. (Obedient and Responsibleness)

Jokowi loves his family and life partner, who he believes are the main driving factors in achieving success, as evidenced by the life he left the company and built from scratch his own family business. (Family and People's Loveness)

9) Jokowi has high faith in his religion and begins his work by praying to his Lord. (The Power of Prayness).

10) Jokowi maintains the kindness of services of his work partners and supporters who made him successful as the leader of this country to take sides with the people and respect the previous leaders with polite ethics in the previous leadership estafet. (Ethics and Partners).

From ten indicators that WLBC view of the leader can be said to have three basic forces that is Power of Family, Peoples, and Responsibilities (The Power of Family, People, and Responsibility).

According to Frederikus Gebze (2019), he explained the character and leadership style of President Jokowi. Honestly, for the rest of my life, this is the first time I have seen a leader of this Republic who is truly clean, populist and a consistent hard worker. Sometimes, I see how close President Jokowi is to his people, and as if there is no distance between him and his people.

Greenleaf, also stated that service-oriented leaders start their actions with integrity, develop relationships of trust, and help others to learn, grow, and develop the ability of these people to lead themselves. The ethics leader is actually committed to 
develop followers, they give the freedom to experiment, take risks, and even make mistakes without fear of punishment.

Hamilton and Nord as cited by Vadell (2009),

The Role of Trust in Leadership: US Air Force oth Officers' Commitment and Intention to Leave the Military) concluded that servant leadership shapes personality characteristics of reflection, integrity, and passion (passion and passion). In this case, a leader must present positive things to his followers. To inspire them to work by the direction and mission of the
organization, the 10 servant leadership attributes presented in Greenleaf's essay are as follows:

Listening. This attribute is a critical means of Commitment to the growth of people. This attribute shows the leader's ability to hold a commitment to the growth of people by a leader through giving appreciation and encouragement to others. As stated by Greenleaf, that "The secret of institution building is to be able to weld a team of such people by lifting them up to grow taller than they would otherwise be".

Building community. This attribute shows the leader's ability to build a community that unites individuals in society. As explained by Greenleaf, "All that is needed to rebuild the community as a viable life form ... is for enough servants to show the way".

Open on basic theory about what the communication, needed so that communication can run leadership style. Leadership style, contains the meaning accurately and actively shows respect for as a manifestation of the behavior of a leader, which others. According to Greenleaf, " Only a true natural concerns his ability to lead. The embodiment usually servant automatically responds to any problem by forms a certain pattern or shape.

listening first".

This definition of leadership style is in

Empathy. Attributes that indicate a leader's accordance with the opinion expressed by Davis and ability to be aware of what others feel. Greenleaf stated Newstrom (1995) . Both state that the overall pattern of that, "The servant always accepts and empathizes, the leader's actions as perceived or referred to by these never rejects" and "Men grow taller when those who subordinates is known as leadership style.

lead them empathize, and when they are accepted for who they are ...".

Healing. This attribute is defined Meanwhile, another opinion states that leadership style by Greenleaf as "to make whole". What this means is is a pattern of behavior (words and actions) of a leader that a leader recognizes the expectation of others to find that is felt by others. (Hersey, 2004) Leadership is out the whole of himself and provide support to someone who can influence other people or groups to others. perform the maximum work that has been determined

Awareness. This attribute is necessary for a in accordance with organizational goals. The leader to gain opportunities as a leader. Without organization will run well if leaders have skills in their awareness, a leader will lose the opportunity for fields, and each leader has different skills, such as leadership

Persuasion. This attribute helps the leader to build group consensus through gentle and clear Discussion

persuasion, and not use group compliance because of The author wants to provide a response to all the positions of power. Greenleaf noted that "A fresh look opinions of the experts above by comparing that every is being taken at the issues of power and authority, and period of leadership, each leader reads and studies and people are beginning to learn, however haltingly, to evaluates both the nature and character of the previous relate to one another in less coercive and more leaders as well as Jokowi views and takes the essence creatively supporting ways". This means that a leader of important things that are prepared for formed his will use his personal strength and not the power of his own nature and character of leadership that will vary power to influence the group and achieve with the nature and characteristics of, but the author organizational goals. analyzes the three main force in view of WLBC you

Conceptualization. This attribute illustrates uploaded by Greenleaf's Servant Leadership Attributes that a leader can find solutions to problems that do not 10 is divided into: currently exist.

Foresight. This attribute shows that the leader has better knowledge and future perspectives on what will happen in the future.

Stewardship. This attribute shows the leader's ability to perform organizational governance. That is, the leader does not only represent subordinates personally, but also represents the organization as a whole, and its impact on the organization's relationship with society.

1) Family Factor: Jokowi formed the character and character that grew from the family, namely as the nature of Conceptualization. At ribut (a solution to a problem that does not currently exist). This happened when he stopped working at the company and started his own Foresight business. Attribute (having better knowledge and future perspective), this happened when Jokowi was evicted three times from his residence.

2) Stewardship. This attribute shows the leader's ability to perform organizational governance. That 
is, (leaders do not only represent subordinates personally, but also represent the organization as a whole, and its impact on the organization's relationship with society). This happened when Jokowi got up his business despite experiencing very formidable challenges and obstacles.

3) People Factor: Jokowi formed his character and character that grew out of society when he started to enter the world of politics and started his career and gained the trust of the people of Solo twice then the Governor of DKI Jakarta and became the 7th and 8th President of the Republic of Indonesia. Commitment to the growth of people. Attributes (a leader's ability to hold a commitment to the growth of people by a leader through giving appreciation and encouragement to others).Building community. Attributes build a community that unites individuals in society.

4) Personal Responsibility: Jokowi is a smart and decisive figure in carrying out the mandate of the Law and the People 's Mandate in accordance with his simple life background and does not require various facilities even though he is the head of state so that the characteristics and characters such as: Listening listens to the voice of the people). Empathy (feeling what the people suffer). Healing (what the people hope). Awareness (the opportunity to help the people when they become leaders).

5) Persuasion. Building compliance without partiality to the group), these five attributes are the 2) responsibility as a leader to uphold the commitment, consistency and consistency that is appreciated in Jokowi.

6) Leadership Style: Our leaders, starting with Former President Dr. Ir. H. Soekarno, Former President General of TNI HM Soeharto, Former President Prof. Dr. Ing. H. Bacharuddin Jusuf Habibie, Former President Dr. KH Abdurrahman Wahid, Former President Dr. Hj. DyahPermata Megawati Setyawati Soekarnoputri, Former President General TNI Prof. Dr. H. Susilo Bambang Yudhoyono, and currently President Ir. H. Joko Widodo has different leadership styles. Some people look at it from the good side, some from the bad side. How will Jokowi's leadership style be classified as a leadership style which includes: Autocratic, Democratic and Laissez faire Leadership Style.

Jokowi's leadership style is very different from 3) previous leaders, even classified as the most unique in the world with the conditions of an archipelago country like Indonesia and with its diversity.

1) Humble. Of all President Joko Widodo's characteristics that he likes most is his humble attitude, he never seems to speak cynically, he always bows down when he meets people, he greets everyone, and he 'ngajeni'
(Javanese language $=$ respect $)$ anyone. This is the character of the Javanese from the side of the common people who are friendly and do not see their position, they see their position as 'Work' rather than social status, so they don't feel more than other people. President Joko Widodo does not like to belittle others, he always praises but is also firm, it seems that President Joko Widodo uses language that is pleasing to his interlocutors, he does not feel himself to be served, he even often feels he has to serve people. This serving character may have been formed since he was a child, when he grew up, he was born in a poor condition and the only way to survive is to serve others, he works to pay for his school, he is responsible for himself and maybe he knows how hard it is to be poor people, how unpleasant 'dadiwongra nduwe' (so people don't have) that people might insult someone, is considered one eye, so when her life is unsettled she is afraid to insult people. He does not hold grudges in his poor past, instead respects the poor, human status is not seen from his wealth, but whether he is useful for many people, is his work beneficial to many people, he may know how it feels to be hurt by an arrogant attitude, that's why he is humble, he humanizes humans, likes to talk in a friendly manner. At this point he never feels more than anyone else, it can be seen from the way he talks and acts.

Sincere. A sincere attitude from someone is seen from the way they talk, the way they work, usually people who are sincere to work without burden and are not bothered by artificial things, sincere people never think of all kinds of 'work, work', there is no need to hide agendas, tricks and anything else that makes him benefit and harm many people. The basic character of President JJoko Widodo's sincerity is seen from the way he ia working for peoples, the most prominent thing is when he doesn't take his salary. When State officials all out of order fund the APBN or APBD through marked up tender projects, President Jokowi does not take his salary, even this has been done since he served as Mayor of Solo. President Joko Widodo has never made a fuss about salaries, he has even forgotten them, from this point of view for public learning that he works sincerely.

In a simple behavior and Talk. President Joko Widodo's favorite character for millions of Indonesians is his 'simple attitude and speech'. Not wearing very expensive clothes, he wore simple clothes, simple shoes, never showed off wealth. We are often sad that amidst the hungry people, many officials are shameless to show off a massive wedding party, how do we feel when we see a child hungry, a child carrying 
meatball merchandise, or a child looking for a fortune by scavenging trash, while the leader marry off her child in a five's high chocolate shower? And the hungry child saw from the TV shows that he only ate salted fish and tofu. President Joko Widodo understands that by being simple he teaches that he does not live in a prison of prestige, it is prestige that makes life expensive, life as it is, no need to show off, even his official car is an old Camry, he is not fussy, then he uses a car. Esemka, if he goes to Jakarta for official purposes, he only takes an express taxi, not using a luxury car. Here he makes an image, because with his wealth he could have bought the latest sedan with a price of over 1 billion, but why buy it if later in the car he sees that many of his people are still hungry and in 5) pain, in simplicity he is united in the mud of the misery of many people.

4) Not Vindictive: The character that President Joko Widodo likes many people is 'Not Vengeful'. He never responds to words that humble himself. He even feels that every word that humiliates him is a blessing from God that he "must" just accept. Maybe the public still remembers a lot about what the Governor of Central Java said when he made a fuss about the ex Gudang Es Sari Petodjo in Solo, who wanted to build a mall, but Mr. Jokowi refused. Then President Joko Widodo 6) (who at that time, as the mayor of Solo) was said to be "Mayor of the Goblok" by the Governor of Central Java, President Joko Widodo did not reply with harsh words but with a casual greeting but did not take it to heart "Lha, I am indeed a stupid person" (President Joko Widodo while laughing) And President Joko Widodo continues with his conviction, he is not resentful but at the same time not wishy-washy. This character is not owned by many current officials who are arrogant, many of the public officials or representatives of the people who are watched by many people such as in the Indonesian Lawyer Club under Karnillyas on TV One, showing off their arrogance, being nudged a little angry, looking right on their own, smart talking but without action and always hold a grudge until it is brought into the audience by the crowd. Now, just before Round II, President Joko Widodo is being criticized, the origins are slandered, accusations that have nothing to do with work performance, etc. are being blown up to convey hatred to groups who have not received information on who President Joko Widodo is. But President Joko Widodo does not retaliate and does not retaliate in an evil way but he retaliates with silence, he is patient in accepting trials, maybe he understands the principle of success in a person's life: 'When someone is tested for their patience, they are being elevated by God, the person who is humiliated is people who when their patience is tested, but instead hold a grudge."And President Joko Widodo has never held a grudge, an incident that has already been done is enough to be a lesson, but one cannot retaliate with a new crime, repay with kindness. The proof is that after being said to be stupid by his boss in Central Java Province, he went to DKI and became the most famous mayor in the history of the Republic of Indonesia. God has raised his rank. Joko Widodo said life is a challenge, don't listen to what people say, the important thing is work, work and work, work will produce something, while talk only produces excuses.

Hard Worker: The most prominent character of President Joko Widodo is a hard worker, he is quick to materialize something from nothing to nothing with his hard work, the way President Joko Widodo works is very similar to Obama's in solving problems, 'Solve from the core of the problem'. President Jokowi is very effective about time, from a young age he has to solve problems quickly, because every postponed problem will cost money and energy, while he knows he is a poor person, so he must be economical, as well as work matters.

Communicative: President Joko Widodo seems to really understand communication science, from this point of view his greatest skills are dialogue and negotiation. When viewed from the way of the language, he is indeed very typical of Solo, his way of speaking is 'Ngglenik' or intimate without limits to his interlocutors, this is the typical way of commoners when they are hanging out. President Joko Widodo does not isolate himself like a sacred aristocrat when talking to the people he leads, he enters the thoughts of his interlocutors by drowning in their subconscious. 'When talking to other people, use that person's language in understanding their mindset' (Soekarno). Principles of Former President Dr. Ir. H. Soekarno was used by President Joko Widodo in understanding how to communicate with his people, his utterances were clear, concise and did not need to be digested complicated. If Donald Trump teaches how to negotiate the 'Win Win Solution', then President Jokowi has very much applied this, the 'Win Win Solution + humanity' method. In negotiations with his job, President Jokowi, on the one hand, can be firm, but also very patient. For example, when he faced the Head of Sub-district and Urban Village who were still stubborn about KTP. He firmly removed officials who failed to implement the effectiveness of the implementation of KTP. But on the other hand, he can be very patient in 
negotiating with the community. Here President Jokowi applies empathy plus integrative communication, which means: he enters into respect and sinks from what the people want. Such as "The people are the storehouse of ideas. Leaders, don't be smart. We are only executors, (President Joko Widodo). One proof of his assertiveness is that Jokowi said in leading me to make people as consumers. And the consumer is king.

7) Tactical: One attitude that is favored by the public towards Jokowi is his ability to think tactically, on the one hand he can think socially, namely: taking collective actions in which the state's wealth can be directed for the welfare of the people at large. On the one hand, President Joko Widodo is very tactical in doing business, he is very business minded, and his brain for this is very watery. Here President Joko Widodo shows that he is not a person who is good at theorizing, but a person who is immediately applicable, he buys clothes that can define himself in the position of public memory, then sells these clothes, he increases public participation, he doesn't need to go out much for campaigns because of clusters. The 9) campaign cluster moved automatically, he taught the public to be political producers, not political consumers. President Joko Widodo is also a person who is very good at seeing problems and their anatomy and quickly arranging positions. As many people underestimate that the city of Solo is homogeneous, Solo is small and so on. Jokowi only answered casually: "Solo is still Indonesia, Jakarta is still Indonesia too, right?" President Jokowi's answer, which seems simple, shows his tactical attitude in dealing with problems. He understands that Solo is a small city but many people don't know Solo is the most plural city in terms of ideology. Solo is the place where major political events in Indonesia began, the worst place when political upheaval occurs, this can be witnessed and examined in the history of the city of Solo, that is, in Solo where people have very characteristics of Jakarta, maybe even more ideological than pragmatic Jakartans.

8) Diverse. President Jokowi's diverse character is very popular with millions of Indonesians, President Joko Widodo teaches that in the public sphere and rational governance it is not good to prioritize different identities such as religion, ethnicity and social status but prioritize achievement, prioritize honesty and ethical values, and bring rationality into the level of political struggle so that the people are taught in choosing rational standards that are put forward, not the measures of God's power such as Religion, Tribe and Social Status. Getting acquainted with Mr.
Jokowi personally through his handwriting is one way to answer some questions from the people of Jakarta, especially regarding the fate of DKI for the next 5 years with the concept of New Jakarta that it carries. Handwriting's President Joko Widodo Answering figure of the leader as if Mr. President Joko Widodo by his personality? Has a vision of the vision to be achieved $\&$ a strong desire to achieve it, seen from its ability to balance the imagination, vision, existing reality \& a strong urge to act to achieve its goals which is reflected in the balance of the zones in his handwriting (red line) Good self-control, careful heart in action and put forward the facts that make him an objective leader. Not emotional \& reactive but using good logic so that they can sort out which ones need an immediate response \& which should be ignored. Because it is not in accordance with the goals it wants to achieve (vertical slant orange line) Friendly and diplomatic so that he is able to integrate himself into various circles easily (garland - yellow circle. In urgent conditions able to make quick but precise decisions (fluidity of thought) - blue circle) Sensitive so that they can empathize well.

Blusukan (Down to The People): Blusukan is a political style that is synonymous with President Joko Widodo. This political style has succeeded in attracting the attention of many people. Many people think that blusukan is very good for leaders to know the condition of their community directly. Since becoming mayor of Solo, Jokowi has often carried out blusukan. Jokowi said leaders should suffer not enjoy. Until he became Governor of Jakarta, he used the style blusukan this as a method of campaign. In the end, he did the same in the 2014 Indonesian presidential election campaign. As a result, this method proved to be both effective and successful in providing a positive image for himself in the eyes of the public. The political style of blusukan in the style of President Joko Widodo then began to become an international discussion since he was elected as the seventh President of the Republic of Indonesia. Not a few media and television in America who preach political style of President Joko Widodo 's. Until finally he became the main topic of TIME magazine. The public thinks that blusukan is considered a completely new way of politics in national and international politics, before being promoted by President Joko Widodo. However, this blusukan actually existed before it was popularized by President Joko Widodo. Today, with the popularity of the term blusukan, politicians have begun to use the blusukan method as a media for their campaign and political strategy. In practical terms, there are four political styles of President Joko 
Widodo that have captured the public's attention. This is because the political maneuvers he has carried out are different from the previous presidents or governors. In a political perspective, this kind of thing is developing the thoughts and ideas of her in studying
commonly done as a new innovation in more in knowledge and values truth of science, the politics. Because the way and style of a person in authors noticed that for the science Leadership of politics will affect his image and image in society. The Behavior will developed into The Leadership of character of President Joko Widodo is closest to and Competitor. No human being is perfect, but work known to the people. But his political chess strategy is honestly and work hard to build goodness for yourself, difficult for any political strategist in Indonesia to your family and society, it's never too late and it's just predict. President Jokowi always issued surprise moves that we can't manage time properly so we wake up and every time he faced pressure from political get up and catch up so it's never too late. Let the time opponents. In the ancient world of martial arts, we that will determine exactly the time that has been know Bruce Lee the master. determined success comes and we are destined to be

Finance Minister Sri Mulyani Indrawati winners that the soul of the leader is already in us and "Maybe if you look at it, the President and the Vice born as leaders.

President are both people who are very diligent in going to the field. From us ministers cannot just work 5. Acknowledgment

behind the desk and talk about policy. This is one of the Thank you to the Center for Research and Community challenges in terms of stamina. Because besides Service, Faculty of Economics and Business, thinking about policy, we think about data, we have to University of Putra Indonesia, Padang, which has go to the field. That is one impression. Both of his provided the opportunity to participate in filling out stamina are extraordinary. So as a minister, I think we journals and to Unisi who has provided many have to be stronger to keep up with."

Coordinating Minister for Maritime Affairs team, Tembilahan, Riau.

and Investment Luhut Binsar Pandjaitan, President Jokowi is a hard worker, brave, and provides protection References

to his subordinates. that I think is an exemplary thing Bangun, P., Djaenuri, A., \& Wildan, L. (2020). for you too. Sometimes people are annoyed and people question or belittle President Jokowi, even though world leaders really appreciate Pak Jokowi and are considered one of the leaders, at least the 13th Islamic world like Muhammad bin Zaid from Abu Dhabi. I think this cabinet has made a very big step and President Jokowi has laid a good foundation in this first term, secondly, he just needs to speed up to speed up all this "

\section{Conclusion}

8. The 10 Characteristics of Jokowi's Leadership Style revealed by Frederikus Gebze are basic traits that were trained, embedded and formed when Jokowi was a child until he grew up and was applied when he was married to the region and led the country. And that Leadership Style becomes Jokowi's character, soul and personality so that the author delivers a view in the process of becoming a leader, Jokowi experiences and lives a concept of "when leaders are born competitors, theory $(W L B C)$, without realizing it we as human beings who are upright on earth are part of the WLBC theory section with various circumstances and atmospirs faced to act as a competitor or competitor and accompanied by a responsibility towards oneself , Jokowi said that education is able to change the way of Hersey and Blanchard (2004) Organizational Behavior life , the family is the biggest source of inspiration and Nurpadillah, V. (2017). Wacana Kepemimpinan: the community around us, so that it makes us do everything effort to live and make a living.
Corruption, Emotional Intelligence, and Leadership: Leadership Analysis From The Seventh President of the Republic of Indonesia. Journal of Public Administration and Governance, 10(1), 100109-100109.

Davis, Keith and Newstrom, John w, (1995) Behavior in organizations, Seventh Edition of Volume One.

Gebze, Frederikus (2019) President Jokowi's Character and Leadership Style

Greenleaf, Robert K. (1970) A Life of Servant Leadership, (James W. Sipe and Don M. Frick, Foreword by Peter $M$ Senge, Afterword by Larry C. Spears, "2009, Seven Pillars of Servant Leadership: Practicing the Wisdom of Leading by Serving)

George Soros, (2019) founder and chairman of the Open Society Foundations, looks before the Joseph A. Schumpeter award ceremony in Vienna, Austria.

Hapsari, S. (2018). Gaya Kepemimpinan Presiden Joko Widodo Dalam Perspektif Sistem Pertahanan Negara Sebagai Upaya Menghadapi Ancaman Asimetrik Abad 21. SALAM: Jurnal Sosial dan Budaya Syar-i, 5(2), 139-146. Analisis Makna Konotasi dalam Teks Pidato Perdana Presiden Jokowi (Leadership Work: 


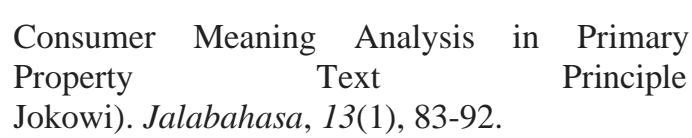

Schwarz, A. (2015, February). Joko Widodo: A New Paradigm for Indonesian Leadership?. In $A$ USINDO Special Open Forum with Adam Schwarz Co-Founding Partner and Chief Executive Officer-Asia, Adam Schwarz's RemarksExecutive Officer-Asia, Adam Schwarz's Remarks.

Sucharithanarugse, W. (2017). Joko Widodo's Leadership. Journal of Politics and Governance, 7(2), 71-79.

Tjiptono, Fandi (2006) Organizational Behavior Zulkarnain, A., \& Harris, S. (2017). Fenomena

Blusukan Dalam Model Kepemimpinan Politik Joko Widodo. POLITIK, 13(1). 